\title{
Os Conflitos Entre o Direito Interno e os Tratados Internacionais*
}

\author{
Vicente Marotta Rangel \\ Catedrático de Direito Internacional Público \\ da Faculdade de Direito da Universidade de \\ São Paulo.
}

\begin{abstract}
Sumário: I. Explicação inicial. II. Perspectivas doutrinárias. III. Direito constitucional internacional. IV. Eficácia internacional das limitações constitucionais. V. Imediatidade dos tratados internacionais em relação à ordem interna. VI. Observações preliminares sôbre o conflito entre o Direito interno e os tratados internacionais. VII. Conflito entre tratados e leis comuns. VIII. Conflito entre tratados e leis constitucionais. IX. O problema das sanções.

$\mathrm{X}$. Conclusões.
\end{abstract}

I.

Explicação Inicial.

O tema que nos cabe relatar se insere no contexto de problemas largamente debatidos e divulgados, quais sejam os das relações entre a ordem interna e a ordem internacional. Mas não apenas êsses problemas continuam a suscitar controvérsias como reclamam soluções específicas para exigências novas que as transformações do Direito e da sociedade estão constantemente a propor.

* Designado relator, o Autor encaminhou o presente estudo, como "ante proyecto de ponencia" ao "VI Congresso do Instituto Hispano Luso-Americano de Direito Internacional", celebrado na Venezuela, de 3-12 de outubro de 1967. 
Quando há três décadas atraz, indagava-se se ainda se poderia tentar acrescentar novo capítulo ao problema das relações entre as duas ordens jurídicas, a resposta não foi senão afirmativa ${ }^{1}$. É a mesma também a resposta em nossos dias, na qual se deve ademais sublinhar a necessidade de que as soluções se revistam de objetividade, se amparem na realidade jurídica tanto quanto social e politica e emerjam dos princípios superiores do Direito.

Cabe-nos examinar, no âmbito desses amplos e relevantes problemas apresentados, tema particular que é de resto circunscrito sob duplo aspecto. A nossa tarefa se restringe a apreciar as relações existentes entre a ordem interna e os tratados internacionais, o que fará com que excluamos de nossa principal cogitação as relações dessa ordem com os costumes internacionais e demais fontes do Direito das gentes. E dentro dessas relações específicas entre a ordem interna e os tratados internacionais, compete-nos focalizar, particularmente, as que se traduzam em relações de conflito, visando, em conseqüência, a determinação das soluções pertinentes.

Nem por ser assim delimitada a área do tema, se deixará de ressaltar o significado que reveste nos dias que correm. Conhece-se a importância que cada vez mais assumem os tratados internacionais, através dos quais os Estados bem como organizações internacionais buscam estabelecer mútuas relações de Direito das gentes. Capazes de revelar com maior tecnicidade o conteúdo dos compromissos das partes celebrantes, e dependentes, por outro lado, da vontade livremente manifestada por essas partes, são os tratados os instrumentos básicos de criação da ordem jurídica internacional. À medida que se amplia o número dêles e o âmbito das matérias por êles versadas, aumenta a freqüência e alcance dos conflitos que estabelecem com o Direito interno dos Estados contratantes.

1. Kopelmanas, Du Conflit entre le Traité international et la Loi interne, in "Revue de Droit International et de Législation Comparée", 1937, pp. 89/90. 
0 estudo completo do tema que nos incumbe examinar - - situado em zona de interferência entre o Direito internacional concebido como disciplina unitária e o Direito público próprio de cada Estado - nos deveria conduzir ao exame preliminar dos diversos ordenamentos nacionais, mormente dos relativos às duas dezenas daqueles que aproximadamente compõem a comunidade hispano-lusoamericana. O tempo de que dispusemos não nos permitiu êsse dever que seria acompanhado ademais da maior satisfação intelectual. Fomos forçados a nos restringir às considerações que se seguem que têm mais o cunho de introdução a estudos que, em relação à matéria focalizada, a seguir deverão ser apresentados.

II.

\section{Perspectivas Doutrinárias.}

Na segunda metade do século XIX, graças à intensificação dos entendimentos entre governos, de que resultou número crescente de convençôes, inclusive coletivas, o problema das relações entre normas de Direito interno e de Direito internacional, passou a reclamar atenção especial. Todavia, bem mais antiga é a preocupação com êsse problema que remonta ao menos há quatro séculos ${ }^{2}$, desde quando, aliás, o aforismo International law is part of the law of the land, passou a informar a jurisprudência dos tribunais de prêsas inglêsas ${ }^{3}$. Foi desde a última quadra do século passado, porém, que se intensificaram os casos

2. Cf. MIAJA DE LA MUELA: Internacionalistas Españoles del Siglo XVI, Fernando Vázquez de Menchaca, 1932, pp. 34-39; Camilo Barcia Trelles: Fernando Vázquez de Menchaca, "Recueil des Cours", 1939-I, pp. 490-492; e, no mesmo sentido, Garcia ARIAS: Adiciones sobre Historia de la Doctrina Hispánica, in "Historia del Derecho Internacional", de ARTHur Nussbaum, Madrid, 1949, p. 404.

3. DICKINSON: L'interprétation et l'application du Droit International, in "Recueil des Cours", 1932-II, pp. 333-335; Idem: Changing 
de contrariedade entre normas de um e de outro Direito, e a obra de Laband, dedicada ao Direito público alemão ${ }^{4}$, teve o mérito de esboçar as linhas básicas de uma teoria que acabou encontrando no livro clássico de Triepel ${ }^{5}$, publicado em 1889, cabal sistematização. A doutrina dualista ou pluralista (também chamada do paralelismo), assim exposta e aperfeiçoada, repercutiu alhures, tanto pela tradução que do livro de Triepel se fêz para o italiano (por Buzzati, Torino, 1913) e para o francês (por Brunet, Paris-Oxford, 1920), como pelo prestigioso curso ministrado pelo jurista alemão, em 1923, na Academia de Direito Internacional de Haia ${ }^{6}$. Evidenciava-se destarte o interêsse que o problema passou a suscitar, de sorte a refletir, como nesse mesmo curso assinalava Triepel, importância tanto teórica quanto prática da matéria. Já desde 1905, o estudo da solução dualista através da jurisprudência da Itália se exprime com o texto publicado em Bolonha, da autoria de Anzilotri ${ }^{7}$ que continuou a recomendar, anos a fio, a mesma solução ${ }^{8}$. A repercussão do sistema dualista se patenteia na seqüência de nomes de juristas que, nesses países e alhures, o perfilharam: Strupp, Hellborn, Wolgast, Drost, Hatschek, Liszt, Walz, Donati, Diena, Cavaglieri, Gemma, Santi Romano, Fedozzi, Perassi, Bosco, Ottolenghi, Sereni, Morelli, Balladore Pallieri, Ago, Redslob, OppeNHeim, Schwarzenberger, Ross, Orúe, Machado Villela entre tantos outros.

Conhecem-se as principais afirmações do dualismo. Cisão rigorosa entre a ordem jurídica interna e a interna-

Concepts and the Doctrine of Incorporation, “AJIL", vol. 26, pp. 239 e segs.; TRUYoL: Noçôes Fundamentais de Direito Internacional Público, Coimbra, 1952, p. 117.

4. Das Staatsrecht des Deutschen Reiches, Tübingen, 1876-1882.

5. Völkerrecht und Landsrecht.

6. Les Rapports entre le Droit Interne et le Droit International, "Recueil des Cours", vol. I, pp. 77-121.

7 Il Diritto Internazionale nei giudizi interni.

8. Corso di Diritto Internazionale, I, Roma, 1928, pp. 49 e segs... 
cional, a tal ponto que se nega possibilidade de conflito entre ambas. Vontade de um só ou de vários Estados como fundamento respectivo dessas ordens: relação de subordinação na primeira e de coordenação na segunda. Distinguem-nas outrossim relações, sujeitos, fontes e estrufuras diversas. Constituem-se como "duas esferas, quando muito tangentes, mas jamais secantes" 9 . Como conseqüência da separação das duas ordens: validade de normas internas contrárias ao Direito das gentes; impossibilidade de que uma ordem jurídica possa determinar a validade das normas de outra ordem; inadmissibilidade e de obrigatoriedade da norma internacional no Direito interno; necessidade de transformação da norma internacional para integrar-se no Direito interno; inocorrência de primazia de uma ordem sôbre outra, por constituirem "dois círculos que estão em contacto intimo mas que não se sobrepõem jamais" ${ }^{10}$. Separam-se nitidamente, pois, o Estado e a ordem jurídica internacional. É o Estado - assinalam ainda os adeptos do paralelismo - o prius lógico do Direito internacional, de modo que aquele não está para êste, senão, ao contrário, "o Direito internacional está para o Estado"

Eis os traços marcantes, sumamente divulgados aliás, da escola dualista, os quais passaram a merecer objeções, todavia, global ou parcialmente, de vários juristas. Não se restringiu Kelsen, o primeiro a formulá-las, a plano meramente crítico senão a passou a perspectivas construtivas, como já as suas obras iniciais o revelam ${ }^{11}$. E no período que separa os anos de 1923 e 1928 - observa Aguilar Navarro 12 - que ocorre "profunda evolução den-

9. TRIEPEL: Völkerrecht und Landsrecht, op. cit. p. 111.

10. TRIEPEL: Les Rapports entre le Droit Interne et le Droit International, op. cit. p. 83.

11. Hautprobleme der Staatsrechtlehre (1911), Das Problem der Souveränität und die Theorie des Völkerrechts (1920) e Les Rapports de Système entre le Droit Interne et le Droit international public, curso professado na Academia de Direito Internacional de Haia (1926).

12. Derecho Internacional Público, tomo I, vol. I, 1952, p. 201. 
tro do movimento kelseniano", a saber: "Verdross expone en tres ocasiones $(1923,1926$ y 1927) su teoria de la stufenbau, a la que hace apoyarse en la existencia de una Constitucion de la Comunidad internacional; Kelsen sale de su "inicial indiferentismo" y se pronuncia en favor de la primacia del Derecho internacional; Merkl y Kunz explican desde un punto de vista empírico y positivo la teoria de la "pirámide" de las normas. En 1927 defienden el monismo con argumentos sociológicos Duguit y Politis y siguiendo sus huellas todos los miembros de la "escuela realista" (Reglade, Scelle. ), así como los más caracterizados miembros del jusnaturalismo." Perfilham e robustecem a tese monista ademais grande número de juristas como Krabbe, Le Fur, Guggenheim, Salvioli, Delbez, Lauterpacht, Brierly, Mirkine-Guetzévitch, Wrigth, Rundstein, Bourquin, Legaz y Lacambra, Miaja de LA Muela, De Luna, Jiménez de AÉchaga, Valladão.

Sustentam os monistas serem a ordem jurídica interna e a internacional componentes de um sistema único, que se escalona segundo um critério hierárquico e que obedece a processo de distribuição de competências disciplinadas pelo Direito das gentes. As dessemelhanças entre o Direito interno e o Direito Internacional não são de essências, senão de grau, meramente acidentais, ou comportam conseqüências técnicas a que o Direito internacional recorre por motivos políticos ou constitucionais, como sucede com a teoria da transformação, a que tanta importância atribuíram os dualistas. Reduz finalmente KELSEN essas diferenças a apenas duas. A primeira é que "os domínios de validade do Direito internacional são em princípio ilimitados, enquanto que o Direito nacional, concebido como o Direito de um Estado, vale sòmente para um território e para um período determinado". A segunda consiste na relativa descentralização do Direito internacional e na relativa centralização do Direito interno ${ }^{13}$.

13. Théorie du Droit International Public, "Recueil des Cours", 1953-III, pp. 183-184. 
Imediatidade das normas internacionais em relação ao direito interno. Equiparação entre sujeitos, fontes, objeto e estrutura das duas ordens juridicas que se comunicam e se interpenetram. Necessidade de optar entre ordens jurídicas conflitantes. Eis demais pontos defendidos pela escola monista.

A opção em favor do Direito interno (Wenzel, Felipe e Alberto Zorn, Decendière-Ferrandière), importou, contudo, em falso monismo, já que deu margem ao reconhecimento da pluralidade de ordenamentos jurídicos internos em função dos quais o Direito internacional se dispersa e esfacela. E atribuir a êsse Direito fundamento meramente constitucional significa desconhecer, por outro lado, o princípio da continuidade das obrigações internacionais e a eficácia de fontes (costumes, princípios gerais de direito) que não dependem da vontade governamental. São essas razões suficientes que explicam não mais possuir representantes a versão do monismo fundado no Direito interno ${ }^{14}$. Duas acabam sendo, na verdade, as teses doutrinárias sôbre o problema das relações entre as ordens juridicas interna e internacional: o dualismo e o monismo fundado no Direito internacional (ou monismo pròpriamente dito). Outras soluções que se acenem com o caráter autônomo não significam senão esforços de aprimoramento dessas teses, às quais acabam a rigor se reduzindo. Êsses esforços são, aliás, meritórios e necessários e importam em significativo progresso da ciência do Direito internacional.

Se bem que os aspectos doutrinários do problema não sejam atualmente descurados, como não o deveriam ser, o certo é que se tem cada vez mais consciência da necessidade de evitar os têrmos rígidos e polêmicos da controvér-

14. MosLeR: op. cit., p. 632; FENWICK: The Progress of International Law during the past forty years, "Recueil des Cours", 1951-II, vol. 79 , pp. 383 e segs. 
sia entre dualistas e monistas, tal como se debatia sobretudo no período que se intercala entre as duas guerras mundiais. Receia-se prevaleça mera disputa de palavras, "vã controvérsia", "diálogo de surdos", o que estimule equívocos e oculte a realidade social e jurídica, da qual se deve partir para o encontro de soluções objetivas que transcendam posições meramente dogmáticas ou apriorísticas. Se o sistema de relações entre as, duas ordens não permanece imutável e esclerosado mas comporta constantes mutações, não se pode deixar de levar em conta que da segunda guerra mundial aos dias de hoje tem aumentado o grau de interdependência dos Estados, se intensificado o processo de internacionalização das matérias, fortalecido o regime das organizações intergovernamentais, e se introduzido inovações relevantes em textos constitucionais que interessam diretamente à nossa matéria.

Cumpre notar, por outro lado, que o decurso dos anos bem como o debate aprofundado das teorias tiveram o efeito de nelas revelar equívocos que hoje os estudiosos puderam melhor identificar. O processo de revisão dessas teorias ganhou impulso. Admite-se excessiva a separação entre as ordens juridicas, que os pluralistas ortodoxos sustentavam, e se reconhece que não a justificam nem o estudo das fontes e dos sujeitos, nem as relações sociais a que essas ordens concernem. Compreende-se a necessidade de superar os fundamentos do positivismo que nutriram a formulação das teses dualistas. Recorre-se a principios gerais de Direito capazes de dar uma visão global e transcendente do fenômeno jurídico. Apela-se para os ensinamentos do processo histórico no qual se possa delinear as coordenadas que distingam o permanente do transitório. E reconhece-se, por outro lado, o exagêro do logicismo com que a tese monista foi elaborada bem como o desconhecimento, de que deu mostras, do caráter próprio e originário da vida social e jurídica do Estado. 
III.

\section{Direito Constitucional Internacional.}

Reparos procedentes se fiseram à doutrina kelseniana, pelo menos tal qual foi inicialmente formulada, a de que ela importava na absorção da ordem estatal pela ordem internacional. E mesmo quando se procurou superar o unilateralismo da concepção normativista e se foi buscar no fato social uma nova dimensão do Direito, continuaram a ter pertinência esses mesmos reparos na medida em que, tal como ocorre na concepção de ScElle, se entendia a ordem interna como proveniente de delegação da ordem internacional e se negavam ao Estado atributos de existência ou de personalidade. Ora, nem a ordem internacional se dilui na ordem jurídica interna; nem esta naquela se dissolve. Igualmente equivocada se mostrou a afirmação de Triepel, a de que essas ordens permanecem reciprocamente indiferentes. Elas, ao contrário, se condicionam e se influenciam mùtuamente.

Seria errôneo supor que da existência do Direito internacional se seguisse necessàriamente a negação do próprio Estado como da existência dêste se inferisse também necessàriamente a negação daquele. A experiência histórica nos mostra que, ao contrário, o esfôrço de organização da ordem jurídica interna se tem feito acompanhar do reconhecimento das normas de convivência internacional e mesmo do desejo de incorporá-las a essa ordem. O cluamado Direito constitucional internacional demonstra, como reiteradamente ensinou Mirinine-Guetzévitch, que a técnica da liberdade e a técnica da paz se unem e se completam. E revela, por outro lado, que tôda constituição estatal concorre para a realização da unidade do sistema jurídico universal ${ }^{15}$

15. Cf. Legaz y LaCAmbra: Las Garantias Constitucionales del Derecho Internacional, in "Horizontes del Pensamiento Jurídico", Barcelona, Bosch, 1947, pp. 27-28. 
É significativo atentar para o fato de que a primeira constituição escrita entendeu corroborar, ao menos em parte, preceito consuetudinário e jurisprudencial que, na Inglaterra, se constituira dois séculos antes: International law is part of the law of the land. Não foi como se sabe, integral a confirmação porque o aforismo dizia respeito a costume internacional enquanto a Constituição norte-americana (de 1787) passou a se referir apenas aos tratados, considerando-os, desde que, concluídos, "sob a autoridade dos Estados Unidos", como sendo também "lei suprema do país" (art. $\left.6 .^{\circ}, \S 2 .^{\circ}\right)$. Conhece-se a influência que essa disposição exerceu alhures. Demonstra-o a Constituição argentina (art. 31). E a mexicana (art. 133) ${ }^{16}$. Consolidou-se ràpidamente, por outro lado, entre os países do Novo Mundo, a consciência de que o Direito Internacional se integra na legislação nacional de cada Estado. Declaração dêsse teôr consta, com efeito, do projeto de Bases Fundamentais, de 1917, do Instituto Americano de Direito Internacional (art. $3 .^{\circ}$ ); do projeto de convenção n. 4 , proposto em 1924, pelo mesmo Instituto, ao Conselho Diretor da União Panamericana; do projeto de convenção n. 1, de 1937, da Comissão Internacional de Jurisconsultos, sediada no Rio de Janeiro.

Foi depois de terminada a primeira guerra mundial que se promulgou na Europa constituição contendo a regra da incorporação das normas internacionais no Direito interno. Sem referir-se especificamente às convenções internacionais, a Constituição de Weimar, de $\mathbf{1 1}$ de agôsto de 1919 , dispôs no artigo $4 .^{\circ}$ : "As regras gerais de Direito internacional constituem parte integrante do Direito do Estado alemão". Repercutiu profundamente êste preceito, como se sabe. Influíu êle diretamente na redação da Constituição da Estônia, de 15 de junho de 1920 (art. $4^{\circ}{ }^{\circ}$ ) e na da Constituição da Austria, de $10^{\circ}$ de outubro de 1920 $\left(\operatorname{art.} 9^{\circ}\right)$.

16. Cf. CÉSAR SEPÚlveda: Curso de Derecho Internacional Público, México, 1960, p. 67. 
Coube à Constituição espanhola de 1931 dar impulso ao sistema da incorporação. Consideravam-se parte integrante da legislação espanhola, "todos os convênios internacionais ratificados pela Espanha e inscritos na Sociedade das Nações e que tivessem caráter de lei internacional". Com essas convenções se conformaria a legislação do país (art. 65, § $1 .^{\circ}$ ). Dispunha outrossim a Constituição que o Estado espanhol acataria "as normas universais do Direito internacional, incorporando-as a seu Direito positivo" (art. $7 .^{\circ}$ ).

No interregno das guerras mundiais, duas constituições ainda entraram em vigor, contendo referências aliás genéricas e menos incisivas que a espanhola, a das Filipinas, de 8 de fevereiro de 1935 , em que se estipulava a integração no Direito nacional dos "princípios geralmente reconhecidos do Direito internacional" (art. $3 .^{\circ}$ ); e a da Irlanda, de $1^{\circ}$ de julho de 1937 , pela qual o país aceitava "os princípios de Direito internacional, reconhecidos como regra de comportamento nas suas relações com os demais Estados" (art. 29, n. 3).

Com o término da última guerra mundial, acentuou-se a tendência do Direito constitucional em refletir as exigências da vida internacional. A Constituição francesa de 27 de outubro de 1946, dizia da conformidade da República em relação "às regras do Direito público internacional" (Preâmbulo, alínea 14) e assegurava a preeminència hierarquica dos "tratados diplomáticos regularmente ratificados e publicados" (arts. 26 e 28). "A República do Equador acata as regras de Direito internacional”, eis a afirmação inicial do artigo $5 .^{\circ}$ da Constituição de 31 de dezembro de 1946. Declara a Constituição da Birmânia, promulgada em 1947, que o país “adota os princípios de Direito internacional geralmente reconhecidos, como regra de comportamento em suas relações com os demais Estados" (art. 211).

Primazia do Direito internacional geral é o que estipulam constituições mais recentes, como a da Itália (art. 10) e da Alemanha Federal (art. 25), de 8 de maio de 
1949, primazia essa que nesta última é mais explícita que naquela. À superioridade dos tratados internacionais sôbre o Direito interno ficou reiterada na Constituição francesa de 28 de setembro de 1958 (art. 55). Essa mesma superioridade consta do artigo 66 da Constituição holandesa, cuja redação obedece às determinações das revisões de 22 de maio de 1953 e de 23 de agôsto de 1956. Não se limitam êsses últimos diplomas legais a proclamar a submissão do Estado ao Direito internacional, o que no julgamento severo de Paul de Visscher, seria ao mesmo tempo inútil e perigoso ${ }^{17}$. Mas concorrem para o cumprimento da missão do Direito constitucional que não é o de reproduzir "las reglas de Derecho de gentes, sino llenar estas reglas, en la medida en que deben encontrar aplicación en el orden interno, de garantías técnicas y procesales que contribuyan a asegurarles el respeto por todos los órganos internos"18. Dar às normas do Direito das gentes vitalidade e eficiência no âmbito interno de cada Estado, eis tarefa essencial e especifica do jurista.

\section{IV.}

Eficácia Internacional das Limitações Constitucionais.

A capacidade dos Estados para concluirem tratados internacionais é decorrência da própria soberania de que usufruem. Não provém essa capacidade tão sòmente dos atributos da personalidade internacional (ANZILOTTI, KELSEN, Strupp, Verdross) ou da competência legislativa (JeAn Huber) senão dos atributos da soberania que, na verdade, os engloba e os transcende (Bonfils, Fauchille, Accioly). "A faculdade de contrair compromissos internacionais é

17. Les Tendances Internationales des Constitutions Modernes, "Recueil des Cours", 1952-I, p. 520.

18. ANTONIO MARín López: El Problema de las relaciones entre el Derecho Interno y el Derecho Internacional en las Constituciones, "REDY', 1952, p. 602. 
precisamente um atributo da soberania do Estado", declarou a Côrte Permanente de Justiça Internacional, na quesião "Wimbledon". À medida que os Estados transferem parte dos poderes da soberania para pessoas de Direito interno (provincias, municipios, Estados federados) ou de Direito internacional (uniões e organizações internacionais), é que essas demais pessoas passam também a se beneficiar com a mesma capacidade de concluir convenções internacionais.

A competência de realizar todos os atos concernentes à conclusão de tratado internacional cabe aos Chefes de Estado e de Govêrno e aos Ministros de Relações Exteriores. Essa competência se amplia aos chefes de missões diplomáticas no tocante às convenções celebradas entre os Estados a que pertencem e os Estados em que os representam; assim como às pessoas acreditadas em conferência internacional ou em órgão de entidade internacional com relação à adoção de texto de tratado por parte dessa conferência ou órgão. Além dessas hipóteses, a competência se estende a pessoas que exibem plenos poderes adequados ou que os venham a ter confirmados pela autoridade competente do Estado a que pertençam ${ }^{19}$. Trata-se de matérias em que importa considerar-se o que disponha o Direito interno dos Estados contratantes (Convenção de Havana, de 1928 , art. $1 .^{\circ}$ ).

Problema clássico e crucial é o de se saber da validade dos pactos internacionais que se concluem com infringência do Direito interno dos Estados contratantes. Contràriamente ao reconhecimento dessa validade são os argumenlos fundados na segurança das transações, na prática diplomática, na eventual ofensa à soberania estatal, na dificuldade de verificação da compatibilidade constitucional, e finalmente na bôa fé dos contratantes (Laband, HeIlborn, Bittner, Vitta, François, Cavaglieri, Anzilotti, Siotto-Pin-

19. Draft Articles on the Law of Treaties, arts. 6.ò e 7.9, International Law Commission, A/CN.4/190. 
tor, Fitzmaurice, Sibert, Scelle, Accioly). Em favor desse reconhecimento são, ao revés, os argumentos baseados na unidade do Direito público, na necessidade de atender à vontade autêntica do Estado contratante e, enfim, nas concepções modernas do govêrno representativo (VatTel, Calvo, Martens, De louter, Fauchille, la Pradelle, Dehousse, Hyde, Liszt, Strupp, Schucking, Westlake, Ch. de Visscher, Mirkine-Guetzévitch, Politis, Spiropoulos, Fiore, Consentini, Oppenheim, Barthélemy et Duez, Chailley, Mervyn Jones, ArÉchaga, Cavaré). Não tem a controvérsia, como se sabe, amparo sereno e definitivo na jurisprudência internacional ${ }^{20}$, e uma mesma decisão judicial (verbi gratia, sentença arbitral de Cleveland, de 1888) tem suscitado interpretação contraditórias (como as de SiotTo-Pintor, em contraposição às de Chailley e AréchaGa).

Empenho da doutrina com o objetivo de anular ou de, pelo menos, reduzir o antagonismo das duas teses (Hall, Basdevant, MaNair, Paul de Visscher, Möller), tem produzido frutos. Prevalece atualmente o entendimento de que a transgressão de normas de Direito interno, concernentes a competência para concluir tratados internacionais, só constitui motivo de nulidade, se atendidas determinadas condições: $a$ ) se a infringência do Direito interno fôr manifesta; e $b$ ) se a parte reclamante não houver anteriormente reconhecido, implícita ou explicitamente, ser válido o tratado cuja irregularidade proclama. A primeira condição se encontra inscrita no art. 43 do Projeto Final da Comissão de Direito Internacional. A última se fundamenta na disposição do art. 42 do mesmo Projeto (A/CN.3/190) : allegans contraria non audienda est (casos Temple e Arbitral Awoard of the King of Spain).

Se a segunda condição deflui do comportamento do Estado contratante, a primeira, ao contrário, decorre de normas de Direito interno que convém sejarn precisas e

20. Cf. Hans BLIX: Treaty-Making Power, Londres-N. York, 1960, pp. 355-368. 
claras, tanto para resguardo dos próprios interêsses dêsse Estado como para aprimoramento da ordem internacional. Para que tais qualidades exornem as normas internas, importa que elas não se apartem, ademais, da realidade social e política a que concernem.

Entre as matérias abrangidas pelas Constituições, se inclui a da distribuição de competência entre os poderes governamentais. Em grande parte dos Estados da comunidade latino-americana se acolhe o preceito de que a conclusão dos tratados internacionais pelo Chefe de Estado depende de aprovação do Poder Legislativo. Nesse sentido ${ }^{21}$ : art. 86 da Constituição da Argentina (aprovada em 1853, reformada em 1860, 1866, 1898, 1957); arts. 58 e 94 da Constituição da Bolívia (aprovada em 1945, reformada em 1947 e 1961 e declarada vigente em 1964); art. 83, n. VIII, da Constituição do Brasil (de 1967); art. 76, da Constituição da Colômbia (aprovada em 1886, e com sucessivas modificações); arts. 121 e 140 da Constituição de Costa Rica (aprovada em 1949 e com sucessivas modificações); art. 43 , inciso $5 .^{\circ}$, da Constituição do Chile (aprovada em 1833, e com sucessivas modificações); art. 118, n. 5, e art. 144, n. 8, da Constituição do Panamá (aprovada em 1946, e com sucessivas modificações); art. 123, 11. 1, da Constituição do Peru (aprovada em 1933, e com sucessivas modificações); art. 37, n. 14, da Constituição da República Dominicana (de 1966); arts. 85, n. 7, e 168 n. 20, da Constituição do Uruguai (1966). Obedece-se a uma tradição que remonta às primeiras Constituições escritas, a dos Estados Unidos, de 1787 (art. 2, secção 2. a, inciso $2^{\circ}$ ), e a da França, de 1791 (título III, cap. II, secção I, art. 3). Com a audição dos poderes executivo e legislativo, atende-se à consideração de que o tratado possui a natureza de lei e se respeita, por outro lado, o princípio

21. Alberto Ulloa: Derecho Internacional Público, tomo II, $4 .^{\text {a }}$ ed., Madrid, 1957, p. 188; Cock ArANGo: Autoridad de los Tratados Internacionales en Derecho Interno de los paises, in "Anuario IHLADI", 
da distinção dos poderes governamentais. Não foi senãu com dificuldades que se veio a admitir a participação do Congresso na elaboração da política exterior francesa ${ }^{22}$, mesmo porque se desatendiam em parte os ensinamentos de Rousseau, de Locke e do próprio Montesquieu ${ }^{23}$.

Prescrever a submissão de todos os tratados internacionais à aprovação do Congresso é preceito, no entanto, que pode não condizer com os requisitos de presteza a que devem as relações internacionais atender ${ }^{24}$. Mas também nem sempre satisfazem êsses requisitos as Constituições que, inspiradas no sistema da Constituição belga de 1831 (art. 68), excluem da competência do Congresso, de cuja autorização ficam excluídos, segundo critério "ratione materiae", determinados pactos ${ }^{25}$. Daí surgirem na prática ajustes executivos ou de forma simplificada que, em dissonância com a letra dos textos constitucionais, e justificados, quase sempre, em nome de eventual costume, dão margem a incertezas que atingem a ordem interna dêsses Estados e a própria ordem internacional. Nem sempre se apresentam revestidos de objetividade os critérios em que se baseia a conclusão de acôrdos de forma simplificada, o que sòmente pode ocasionar distorsões da ordem jurídica e prejuizos a partes contratantes. Donde ser conveniente que as Constituições passem: a) a determinar com rigor os casos em que as convenções demandem ou não a aprovação

22. Cí. FUGIER: La Révolution Française et l'Empire Napoléonien, Paris, Hachette, 1954, pp. 21/22.

23. Cf. MirKine-Guetzévitch : op. cit., pp. 356/359.

24. Cf. Alberto UlloA: op. cit., pp. 188/190; Accroly: Ainda - Problema da Ratificação dos Tratados em face da Constituição Federal Brasileira, "BSBDI", n. 13-14, pp. 33 e segs.; NAScimento E Silva: A Referenda pelo Congresso Nacional de Tratados Internacionais, in"Direito", vol. Xlvi, pp. 41-46; J. H. Pereira DE Araujo: A Processualística dos Atos Internacionais, Rio, 1958, pp. 172-173.

25. Cf. C. Chayet: Les Accords en Forme Simplifiée, "Annuaire Français de Droit International", 1957, pp. 4 e segs.; Clive Parry: Some Recent Developments in the Making of Multi-Partite Treaties, in "Transactions", The Grotius Society, 1950, vol. 36, pp. 30 e segs. 
prévia dos órgãos legislativos ou dos demais órgãos governamentais competentes; $b$ ) e, mesmo mantido o princípio de que tôdas as convenções necessitem de serem aprovadas pelo Congresso, prescrevam, em hipóteses devidamente caracterizadas, medidas destinadas ao apressamento da conclusão dos pactos internacionais.

V.

Imediatidade dos Tratados Internacionais.

É ponto fundamental da tese dualista a peculiaridade de formação e de aplicação das normas de cada ordenamento jurídico. Tanto quanto uma fonte de Direito interno não pode ser fonte de Direito internacional, esta com aquela também não se identifica. As normas internacionais "não podem influir sôbre o valor obrigatório das normas internas, e vice-versa" ${ }^{26}$. Não geram aquelas normas senão obrigações de Estado para Estado. Podem, quando muito, ser convite a gerar Direito interno, cuja criação, no entanto, vai depender estritamente da vontade de um só Estado. As fonies do Direito interno devem agir por si próprias para fazer com que se torne seu o direito criado pelas fontes do Direito internacional. $\mathrm{E}$ devem as normas internacionais transformarem-se em internas (lei, decreto, regulamento) para que delas possam nascer deveres e direitos individuais e obrigações específicas de órgãos internos, administrativos ou judiciais ${ }^{27}$. Sem explicarem a contradição em que incidem ao entenderem que êstes órgãos apenas e não os legislativos se subtraem aos efeitos diretos da norma internacional ${ }^{28}$, insistem os dualistas na repro-

26. ANzilotTr: Cours, trad. Gidel, I, pp. 50 e segs.

27. TRIEPEL: Völkerrecht und Landsrecht, pp. 110 e segs.; Idem: giudizi interni, pp. 114 e segs.; STRUPP: Éléments du Droit InternaLes Rapports, pp. 83-84; ANZILotT: Il Diritto Internazionale nei tional Public, 1927, pp. 14 e 182.

28. Cf. Jiménez de ARechaga: Curso, I, pp. 186-187. 
dução das normas internacionais pelo Direito interno através do processo que Triepel denomina de recepção ${ }^{29} \mathrm{e}$ ANzilotTI ${ }^{30}$ de reenvio com recepção, e que acarreta transformação tríplice: a do valor, a da destinação e a do conteúdo dessas normas.

Certo é, porém, segundo sustenta a escola monista, que o Direito internacional, costumeiro ou convencional, penetra de plano na ordem interna. A passagem de uma para outra ordem jurídica se processa mediante determinado automatismo e sem que se exija das normas a transformação enfocada pela escola oponente. O que ocorre é nova adoção da ordem jurídica internacional que, como tal, se insere na ordem interna de cada Estado.

Se tomarmos como referência os princípios gerais de Direito (Estatutos da C. I. J., art. 38, n. 1, c), nem mesmo, a rigor, essa passagem de uma ordem a outra existe. Constituem êles, como assinala Sörensen, "o cimento que assegura a coesão do Direito internacional com as ordens jurídicas nacionais e que permite conceber todos os fenômenos jurídicos da humanidade sob um aspecto de unidade". Expressão direta do Direito objetivo, podem ser invocados "contra um Estado que pretenda nunca os ter admitido" ${ }^{31}$.

O exame do problema à luz do Direito positivo reclama se leve em conta distinção entre normas consuetudinárias e normas convencionais.

A integração das normas consuetudinárias no Direito interno tende, em princípio, a confirmar a tese monista, e a elas concerne a regra International law is part of the law of the land que, aliás, não faz parte apenas dos países de sistema jurídico anglo-saxônico senão também é comum

29. Les Rapports, p. 92.

30. Op. cit., p. 61 .

31. Accioly: Tratado de Direito Internacional Público, I, 2. ${ }^{\mathrm{a}}$ ed., Rio de Janeiro, 1956, p. 37. 
a todos os países ${ }^{32}$. Explicitam essa regra diversas Constituições contemporâneas, como a da República Federal da Alemanha (art. 25), da Italia (art. 10), da Austria (art. 9), da Coréia do Sul (art. 7) e das Filipinas (art. 2, sec. 3). Conquanto dúvidas se levantassem acerca do alcance do artigo 25 da Lei Fundamental da República Federal da Alemanha, não as alimentou a Côrte Constitucional dêste país, que, ao julgar o processo sôbre Concordata, a $27 \mathrm{de}$ março de 1957, asseverou que "as regras gerais do Direito internacional são diretamente incorporadas, sem lei transformadora, na ordem jurídica alemã e nela predominam sôbre as normas internas alemãs" ${ }^{33}$.

Apesar do silêncio da Constituição da França quanto ao efeito interno das normas gerais, de Direito consuetudinário inclusive, a jurisprudência dêsse país as tem reconhecido e aplicado. Em relação à Suíça, as normas de Direito internacional costumeiro também não necessitam de nenhum processo especial para se incorporarem ao Direito interno em o qual "têm validade imediata" ${ }^{34}$. Trata-se de preceito claramente sufragado pela jurisprudência interna desde que o Tribunal Federal o admitiu na sentença de 13 de março de 1918, referente ao processo "Ministério das Finanças da Austria v. Dreyfuss". O juiz holandês, por seu turno, se considerou sempre com competência para aplicar o costume internacional, sem exigir que fôsse prèviamente aceito, confirmado ou transformado pelos órgãos governamentais. Aplica-o tal como é, diretamente, na qualidade de norma internacional ${ }^{35}$.

32. PAUL DE VISSher: Les Tendances Internationales des Constitutions Modernes, "Recueil des Cours", 1952-I, pp. 523-525.

33. BVERFGE vol. 6, p. 309, apud LARDY: La Force Obligatoire du Droit International en Droit Interne, Paris, 1966, p. 54.

34. Guggenheim: Droit International Public, I, p. 35.

35. L. ERADES e W. L. Gould: The Relation between International Law in the Netherlands and in the. United States, Leyden-N. York, 1961, p. 226. 
A relação de imediatidade entre as normas consuetudinárias internacionais e do Direito interno dos Estados Unidos é explicitada na sentença da Côrte Suprema dêsse país, no conhecido caso do Paquete Habana e do Lola, capturados por navios de guerra junto à costa de Cuba, durante a guerra hispano-norte-americana. Reconheceu e aplicou êsse tribunal, independentemente de qualquer norma interna, regra consuetudinária de Direito internacional, segundo a qual os barcos de pesca não são bôa prêsa.

Dispunha a Constituição espanhola de 1931, no art. $7 .^{\circ}$, como acima se disse, que o govêrno respeitaria "as normas universais do Direito internacional, incorporando-as ao seu Direito positivo". Conquanto haja sido revogada a Constituição - explica MiAJA DE LA Muela - a regra da incorporação não caducou, "ni hay motivo que permita suponer que España se haya desentendido unilateralmente de la obligación que un día asumió" ${ }^{36}$.

Baseado na jurisprudência e na prática de seu país, observa, por sua vez, JimÉnez de ARÉchaGa: "Respecto. al Derecho internacional de origen consuetudinario, los jueces y órganos administrativos del Uruguay hacen una aplicación directa e inmediata de esas normas a los particulares" ${ }^{37}$. Solução similar é a da Constituição argentina, cujo art. 102 se refere - diz Bidart Campos - a "Derecho de gentes", sendo certo, ademais, que a Côrte Suprema e os tribunais federais têm competência de conhecer e aplicar normas de Direito consuetudinário internacional ${ }^{38}$.

Quanto à integração das normas convencionais na ordem estatal, o que constitui objeto principal dêste relaiório, as soluções do Direito positivo não apresentam a mesma uniformidade.

36. Introducción, op. cit., p. 133.

37. Op. cit., p. 197. Igualmente, do mesmo autor: Introducción al problema de las relaciones entre el Derecho Internacional y el Derecho Interno, in "Revista Jurídica de Buenos Aires", 1962-I-II, p. 22.

38. Relaciones entre Derecho Internacional y Derecho Interno en la Doctrina y en el Derecho Comparado, in "Revista de Derecho Españo]. y Americano", 1965, p. 108. 
Em relação ao Direito positivo de alguns países, a carência de uniformidade atinge a própria interpretação que dêle se faça. É o caso do Direito inglês que, conforme doutrina dominante (Triepel, Rousseau, Walz, Mosler, PhiLIPPE Comte), segue os preceitos do dualismo, uma vez que o tratado se incorpora ao Direito interno sòmente através de lei. Segundo alguns autores, no entanto (Lavterpacht, ArÉchaga, p. ex.), a necessidade de ato de transformação interna visa a atender exigências do Direito constitucional e não possui o alcance apregoado pela doutrina dualista. De outro lado, como nem todos os tratados requerem intervenção parlamentar ${ }^{39}$, segue-se que o Direito internacional convencional pode ser diretamente aplicado por órgãos estatais judiciais e administrativos. O mesmo sistema inglês se divisa no Canadá, na Austrália, Nova Zelandia, Africa do Sul, India, e parece ter inspirado - diz Mosler ${ }^{40}$ - as Constituições escritas de países que fizeram outrora parte do império britânico: Irlanda e Birmânia. Essa influência também atinge a Israel.

O princípio do sistema britânico é o de que compete apenas ao poder executivo pronunciar-se sôbre o cumprimento das obrigações internacionais. "Cabe-lhe, se estimar' oportuno e quando julgar oportuno, pedir ao Parlamento votar uma lei que transformará a norma internacional em regra jurídica interna". O tratado em si não concerne, porém, aos governantes (executivo). É o que, no mesmo sentido, reza a Constituição da India, cujo artigo 37 proibe aos tribunais imporem ao govêrno a observância dos princípios diretores da política geral do Estado, inclusive os referentes às relações internacionais ${ }^{41}$.

39. Cf. Mc NAIR: L'application et l'nterpretation des Traites d'après la Jurisprudence Britannique, "Recueil des Cours", 1933-I, pp. 253-262.

40. L'Application du Droit International Public par les Tribunnaux Nationaux, "Recueil des Cours" 1957-I, p. 649.

41. Philippe Comte: L'Application de la Convention Européenne des Droits de L'Homme dans l'Ordre Juridique Interne, in "Revue de la Commission Internationale de Juristes", 1962, tomo IV, p. 118. 
A jurisprudência de tribunais de países, como a Irlanda e a Islândia, que são partes da Convenção Européia dos Direitos Humanos, reflete, segundo assinala Philippe Com$\mathrm{TE}^{42}$, os postulados da escola dualista. Sustentou a Suprema Côrte da Irlanda, que, por fôrça da Constituição de 1937, aquela Convenção não poderia ter aplicação uma vez que não havia sido recepcionada por lei interna. Argumento similar, conquanto desacompanhado de texto formal, invocou o Tribunal Municipal de Reykjavik, em sentença de 28 de junho de 1960, para declarar que a mesma convenção não possuía na Islândia fôrça de lei.

A tradicional tendência dualista da doutrina italiana tem repercutido na técnica da introdução do tratado internacional. Essa introdução se faz através de uma "ordine di esecuzione" considerada como ato legislativo, "verdadeiro e próprio". A disposição do art. 10 da Constituição italiana - "dispositivo di adeguamento automatico" não se estende aos tratados internacionais. É o entendimento da jurisprudência com apoio na doutrina ${ }^{43}$.

A maioria dos Estados adota sistemas que refletem os postulados da escola monista, e o faz sem que se suscitem maiores controvérsias a respeito. A mais antiga das Constituições escritas admite, como se anotou, a incorporação imediata das disposições dos tratados no direito interno, considerando-os também como supreme Law of the Land (art. VI, secção II). A ratificação assimila o tratado à lei interna e o torna imediatamente aplicável em relação tanto às autoridades como aos indivíduos.

Havia a Constituição de Weimar enunciado valerem como parte integrante do direito alemão "as regras geralmente reconhecidas do Direito internacional" (art. $4 .^{\circ}$ ).

42. Op. cit., pp. 116-119; no que aliás é acompanhado por BIDART CAMpos, op. cit., p. 123.

43. Balladorf Pallieri: La Nuova Costituzione Italiana, Milano, 1948, p. 7; CeRETTI: Corso di Diritto Costituzionale Italiano, Torino, 1948, p. 261; Miele: La Costituzione Italiana e il Diritto Internazionale, Milano, 1951, pp. 21-27. 
Entendeu-se, contudo, que essa disposição não se referia ao Direito internacional convencional, o qual sòmente se introduziria na ordem interna mediante prévia lei de aprovação. A Côrte Suprema havia, além disso, proclamado a assimilação da aprovação parlamentar às leis ordinárias ${ }^{44}$. Refere-se o artigo 25 da Lei Fundamental da Alemanha Federal igualmente às "regras geralmente reconhecidas do Direito internacional" que não abrangem, como se sabe, as regras convencionais. Em matéria de tratados internacionais, dispõe contudo a mesma Lei Fundamental que os acôrdos concernentes às relações diplomáticas da Federação ou às matérias dependentes da legislação federal, necessitam "do consentimento ou do concurso das Assembléias Legislativas federais competentes conforme o caso, sob a forma de leis federais" (art. 59, n. 2). Discutese a natureza dessas leis. Teriam elas a finalidade de transformar a convenção internacional em normas internas (tese dualista)?; ou, ao contrário, traduziriam elas apenas uma etapa na elaboração do tratado ainda no plano interestatal (tese monista), de tal maneira que, concluido o tratado neste plano o teria sido também no plano interno, produzindo em ambos concomitantemente efeitos de Direito? Aplicaria o juiz a própria convenção internacional, ou, ao revés, uma lei interna em a qual aquela se houvesse transformado? Esta última hipótese, que permite por via oblíqua o contrôle da constitucionalidade dos tratados, é que tem sido sufragada pela jurisprudência germânica, se bem que com oposição de parte sensivel da doutrina (KAUFman, Mosler, Mangoldt-Klein). Porém, o reconhecimento da imediatidade dos tratados no âmbito interno não é, no direito germânico, pôsto em causa. Admite-se, outrossim, beneficiarem-se da imediatidade das convenções das comunidades européias (CECA, Euratom, Mercado Commum), os

44. LARDY: op. cit., p. 41. 
atos que dos órgãos dessas comunidades emanarem. Têm êsses atos fôrça obrigatória na ordem interna alemã sem necessidade de legislação na qual se convertam ${ }^{45}$.

Diferentemente do que ocorre com as Constituições dos países limitrofes, a Constituição helvética não contém disposição concernente às relações entre convenções internacionais e Direito interno. A prática, a jurisprudência e a doutrina autorizam a dizer, contudo, que o tratado internacional adquire, desde que vigore entre as partes contratantes, fôrça obrigatória na esfera jurídica suiça. Essa aplicação imediata dos tratados é igualmente consagrada pela legislação interna ${ }^{46}$.

Conquanto seja também silenciosa a êsse respeito a Constituição austríaca, se tem entendido que os tratados influem no Direito interno, sem necessidade de prévia transformação 47 .

Competia tradicionalmente, na França, à jurisprudência definir as relações entre Direito interno e Direito internacional, sôbre as quais se mantinham omissas as constituições. A primeira a se pronunciar sôbre a matéria foi a de 1946, cujo artigo 26 dispõe: "Os tratados diplomáticos regularmente ratificados e publicados têm fôrça de lei mesmo no caso em que sejam contrários às leis internas francesas, sem que haja necessidade para assegurar-lhes a aplicação doutras disposições legislativas além daquelas que seriam necessárias para assegurar-lhes a ratificação" Confirmava-se assim o princípio da imediatidade que a jurisprudência já havia reconhecido na III República. Esse princípio se encontra reiterado na Constituição de 1958 com uma limitação que não subsistia na

45. LARDY: op. cit., p. 82.

46. GugGenheim: Traité de Droit International Public, I, 1953, p. 36; Idem: Enquête sur la Manière dont les Etats conçoivent leurs Obligations Internationales, Unesco, 1955, p. 12; LARDY: pp. 197 e segs.

47. SEIDL-HOHENVELDERN: Relations of International law to Internal in Austria, "AJIL", vol. 49, 1955, pp. 451 e segs. Igualmente, Philippe Comte: op. cit., p. 121. 
anterior de 1946, a da cláusula da "reciprocidade" Mas esta limitação, como é notório, não atinge a própria sủslância da regra da imediatidade.

Não possuía a Constituição holandesa, até a revisão de 1953, nenhuma regulamentação expressa da aplicação dos tratados internacionais embora a jurisprudência e a doutrina lhes reconhecessem fôrça obrigatória imediata na esfera interna, contanto que fôssem regularmente concluídos. "As disposições dos tratados que impõem obrigações aos particulares" - dispõe atualmente a Constituição "têm fôrça obrigatória desde a sua publicação"

Entre os países da comunidade hispano-luso-americana, parece prevalecer postulado da escola monista, uma vez que os tratados devidamente concluídos no plano internacional não necessitam, para que sejam aplicados internamente, de lei na qual se transformem. A manifestação do Congresso através de ato formal visa a traduzir a aprovação do tratado que se pretende concluir. Esse ato se intercala como etapa do processo de conclusão e não do processo de execução dos acôrdos internacionais. É o que ocorre, por exemplo, na Espanha. "Pues, en efecto" pondera Pastor Ridruejo - " "al no ser necesaria en principio la transformación de los tratados en leyes, dado que aquéllos forman parte por sí mismos de la legislación espanola, no hay que dictar sino las leyes necesarias para la ejecución de sus prescripciones" ${ }^{48}$. Depois de mencionar o art. 31 da Constituição e os arts. $1 .^{\circ}$ e 21 da lei n. 18, esclarece, por outro lado, Bidart Campos sôbre o sistema de seu país: "El tratado no precisa de la muleta de una ley para incorporarse al orden juridico argentino. La ley aprobatoria no es fuente de recepción" ${ }^{49}$. Ao referir-se ao sistema uruguaio, diz Jiménez de ArÉchaga que a intervenção parlamentar ocorre com o propósito de aprovar ou não o tratado: "no puede tener, por lo tanto, el carácter de transformación de una regla de Derecho internacional

48. Op. cit., p. 48.

49. Relaciones, op. cit., p. 126. 
en regla de Derecho interno, sino que es una etapa en el proceso de formación de la regla de Derecho internacional" ${ }^{50}$. Também, ao interpretar a Constituição de seu país, na qual se inclui disposição (art. 133) inspirada na "Supreme Clause" norte-americana, tem a Côrte Suprema do México decidido que os tratados possuem fôrça de lei na ordem interna e se endereçam a todos os cidadãos ${ }^{51}$. A promulgação tem por conseqüência tornar o tratado executório na ordem interna. É o que diz Acciolx, ao ter em conta inclusive o Direito brasileiro, lembrando outrossim as afirmativas de WrLcox, segundo as quais a promulgação é "mera formalidade", "não tem a função de criar nova lei", "apenas certifica a regularidade de uma lei já existente" 52 .

Quanto à jurisprudência internacional, tem ela reconhecido que os tratados internacionais podem produzir efeitos direta e imediatamente na ordem estatal e mesmo estabelecer normas jurídicas diretamente aplicáveis aos particulares. Foi o que decidiu a sentença arbitral de 21 de outubro de 1861, proferida pelo Senado de Hamburgo, na questão Yuille, Shortridge e Cia., entre Grã-Bretanha e Portugal. Admitiu essa decisão que pessoas físicas podem renunciar a direitos instituídos em convenções internacionais ${ }^{53}$. Também a Côrte Permanente de Justiça Internacional, no parecer consultivo de 3 de março de 1928, sôbre a competência dos tribunais de Dantzig em relação a funcionários das estradas de ferro polonesas, entendeu que êsses tribunais tinham o direito e o dever de aplicar a êsses funcionários o acôrdo de 22 de outubro de 1921, subscrito pela Polônia e Dantzig ${ }^{54}$.

50. Curso, p. 199; Introducción, p. 24.

51. Cf. Evans: Treaty Enforcement and the Supreme Court of Mexico; SEPÚlvedA: Curso, pp. 67-71.

52. Tratado, I, op. cit., pp. 602-603.

53. La Pradelle e Politis: Recueil, tomo II, pp. 105-107 e 114-116.

54. Publications de la Cour, série AB, n. 28, p. 17. Cf. Rousseau: Principes, op. cit., p. 438. Em sentido contrário: Cavaré: Le Droit International Public Positif, II, 2. ${ }^{\circledR}$ ed., 1962, p. 135. 
Reafirma, portanto, a jurisprudência internacional o que o Direito interno de diversos Estados atesta: a possibilidade de os tratados produzirem efeitos diretamente no âmbito da ordem estatal. É o que, de resto, se comprova com o progresso do Direito comunitário e o favorecimento, cada vez mais acentuado, do acesso da pessoa humana às instâncias internacionais.

Contra a tese dualista, parece impor-se por outro lado, o fato de que nem todo o tratado pode ser transformado em lei, o que concorreria para destruir a unidade das cláusulas convencionadas; a necessidade da jurisprudência em interpretar o próprio tratado, o que nem sempre significa interpretar a lei na qual o tratado se converteu; e enfim, a diversidade artificial que se vai suscitar entre duas espécies de Estado: o que se compromete na ordem internacional e o que não se compromete na ordem interna. Os requisitos que se devem reclamar na fase de elaboração do tratado devem concorrer não para tumultuar senão para facilitar o processo de execução do mesmo tratado.

\section{VI. \\ Preliminares sôbre o Conflito.}

Entre as observações de caráter preliminar e genérico que cabe formular em matéria de conflito de tratados com leis é, precisamente, que êsse conflito é mais raro de suceder do que à primeira vista se poderia cogitar e, além disso, sòmente ocorre como etapa final de un processo. A solução do conflito acaba sendo o têrmo conclusivo dessa etapa.

Cumpre esclarecer, em primeiro lugar, que a contrariedade entre duas normas há de pressupor que ambas estejam devidamente concluídas ou, em termos mais precisos, que ambas existam. Não há falar em conflito quando está em jôgo simples projeto de lei, ou tratado de natureza 
solene tão sòmente assinado. Seria um falso conflito. Este se estabelece entre normas vigentes.

É oportuno também recordar que determinadas normas, por motivo de conteúdo ou de finalidade, não são de molde a suscitarem antinomias. Lembram-se tratados de aliança, pactos de organização geral ou regional, o Estatuto da Côrte Internacional de Justiça, que dificilmente colidiriam com normas de Direito interno. São exemplos dados por CÉSAR SEPúlveda ${ }^{65}$, ao relatar tema estudado pelo VI Congresso Internacional de Direito Comparado, de Hamburgo, 1962. Cita McNaIR, outrossim, os tratados de garantia entre os quais o de Locarno, como sendo acordos que não se envolvem com o Direito interno e que não são discutidos perante os tribunais inglêses ${ }^{56}$.

Não são igualmente aptas a entrarem em colisão com normas de Direito interno as convenções que delas dependam para se completarem. Para se tornarem executórias na ordem estatal, necessitam essas convenções de fazerem remissão a normas dessa ordem, quer já existam, quer devam ainda existir. Lembra GugGENHeIm que a execução de decisões da Côrte Internacional de Justiça (art. 94 da Carta das Nações Unidas) pode exigir a elaboração de atos jurídicos internos tanto quanto podem reclamá-los as disposições da Carta concernentes à organização da segurança coletiva ${ }^{57}$ Casos que, eventualmente, ocorram de colisão podem não ser a rigor entre convenções e leis, mas de leis entre si, a algumas das quais as convenções se limitam a fazer remissão.

Adquire especial relevância, dentro dessa ordem de idéias, a distinção entre tratados auto-executórios (self-exe-

55. La Autoridad de los Tratados Internacionales en el Derecho Interno, in "Boletín del Instituto de Derecho Comparado de México", 1962, n. 45, pp. 513-514.

56. L'application et l'interprétation des Traités, "Recueil des Cours", 1933-I, p. 253.

57. Enquête sur la manière dont les Etats concoivent leurs obligations internationales, Unesco, 1955, pp. 13-14. 
s:uting) e tratados não executórios (non self-executing), posta em relêvo pelo sistema jurídico anglo-saxônico, com ressonância em outros sistemas. Não basta que o tratado produza efeitos no Bireito interno, quer por via de adoçâo, quer por via de transformação. Para que possa entrar em colisão com lei (norma de origem exclusivamente interna), mistér se faz que o tratado seja self-executing, se revele suficientemente "amadurecido e claro" 58 , para ser imediatamente aplicado. Essa qualificação depende de interpretação, análise da intenção das partes, do objetivo colimado pelo tratado. Se o objetivo é criar imediatamente direitos e obrigações de particulares, o tratado se endereça aos tribunais, e é self-executing. "É a mesma solução - observa Kaufman ${ }^{59}$ - que a Côrte Permanente de Justiça Internacional consagrou no parecer consultivo a respeito dos funcionários de Dantzig, em que a Côrte declara que o próprio fim do tratado podia ser a adoção de normas destinadas a individuos e susceptiveis de serem aplicadas por tribunais nacionais".

Essa distinção, não há dúvida, restringe as hipóteses de incidências entre convenções e leis. Também as restringe a interpretação que das normas se faça com aplicação da regra legi speciali per generalem non derogatur, quer se outorgue à norma interna, quer se atribua ao tratado, a qualidade de lei especial. Habitualmente, porém, se qualifica a interna de geral e o tratado de especial.

Pondere-se que a tendência da jurisprudência é a de admitir uma presunção de compatibilidade entre normas internacionais e normas internas. É regra de interpretação antiga. Marshall a enunciava em 1804, na sentença referente a Murray v. Schooner Charming Betsy: "Uma lei do Congresso não deveria jamais ser interpretada como violando o Direito das gentes, enquanto permanecer susceptível de outra interpretação". Tem esta presunção (aco-

58. MOSLER: p. 664.

59. Op. cit., p. 394 . 
lhida nas jurisprudências inglêsas, norte-americanas, belgas, italianas, suíças, holandesas, entre outras) o mérito de permitir ao juiz salvaguardar o respeito devido aos tratados ${ }^{60}$. Mas tem grave demérito; o de pretender evitar a responsabilidade internacional dos Estados em que a regra de interpretação fôr aplicada ${ }^{61}$. Foi essa regra utilizada - com críticas procedentes da doutrina - no cotejo da Convenção franco-espanhola de 1862 com os decretos-leis franceses de 17 de junho e de 11 de novembro de 1938. Enquanto a Convenção previa que os cidadãos dos dois países podiam "exercer toute espèce d'industrie, faire le commerce tant en gros qu'en détail", com a única restrição de se conformarem com as condições legais impostas aos nacionais, aquêles decretos passaram a condicionar o exercício do comércio de qualquer estrangeiro à posse "d'une carte de commerçant" ${ }^{62}$. A mesma interpretação restritiva tem, como se sabe, sido feita em relação ao artigo 177 do Tratado de Roma (sôbre a Comunidade Econômica Européia), o que tem suscitado observações críticas da doutrina ${ }^{63}$.

Outra consideração fundamental a suscitar no exame preliminar do problema do conflito diz respeito à qualidade ou espécie do tratado que colide com a ordem interna. É questão que nos leva a ter em conta hierarquia já não entre norma estatal e norma convencional, mas dos próprios tratados entre si.

Essa questão tem sido argüida pela jurisprudência alemã. Como acima se disse, dispondo a Lei fundamental da Alemanha Federal que as "regras gerais do Direito internacional" preponderam sôbre as leis (art. 25), se tem entendido que os tratados não se beneficiam de qualquer

60. PaUl DE Visscher: p. 546.

61. Cf. GugGenheim: Enquête..., p. 15; MASTERs: International Law in National Courts, N. York, 1932, p. 100-103.

62. Cf. LARDY: p. 142.

63. Cf. LARDY: pp. 145-156; BATAILLER: Le Juge interne et le Droit Communautaire, "Annuaire Français de Droit International", 1963, pp. 735 e segs. 
preponderância em relação à ordem interna. Esse entendimento comporta, porém, uma ressalva que diz respeito aos "tratados simplesmente confirmativos de regras gerais já em vigor ou aqueles cujas normas adquirem valor de regra geral em razão do grande numero de Estados que a êles aderiram". Tais tratados - escreve LARDY ${ }^{64}$ - gozam da preeminência enunciada no artigo 25 da Lei Fundamental, "possuem fôrça suprema na ordem interna e podem mesmo derrogar a Constituição".

\section{VII.}

\section{Conflito entre Tratados e Leis Comuns.}

Ponto básico na doutrina dualista, como se sabe, é a eliminação teórica de tôda possibilidade de conflito entre a lei e o tratado internacional. Pertencem a ordens rigidamente separadas. É possivel o conflito apenas se a norma internacional se converter em norma interna. A colisão dar-se-á então entre duas leis, uma com origem na própria ordem estatal, outra nascida da transformação de convenção internacional. Não há relação de hierarquia entre as duas leis. Se conflito entre ambos ocorrer, ele se resolverá com a aplicação do aforismo lex posterior derogat legi priori. É o que expõem vários autores ${ }^{65}$. Ou em têrmos adequados ao tema aqui examinado, o conflito se resolverá com a adoção da regra que o juiz norte-americano Taft, na sentença de 18 de outubro de 1923, dizia ter alcance univelsal: "a treaty may repeal a statute, and a statute may repeal a treaty" 66 .

64. Op. cit., pp. 81-82.

65. TRIEPEL: Droit International et Droit Interne, trad. francesa, pp. 252 e segs.; Les Rapports, op. cit., p. 83; WoLGast: Völkerrecht, Berlim, 1934, pp. 966 e segs.; STRupP: Règles Générales du Droit de la Paix, "Recueil des Cours", 1934-I, pp. 404 e segs.; ANZILotTi: Cours, op. cit., pp. 42 e segs.; CAVAGLIERI: Corso di Diritto Internazionale, Napoles, 3. ${ }^{\text {a }}$ ed., 1934, pp. 19 e segs.; Balladore Pallieri: Diritto Internazionale Publico, Milán, 8.a ed., 1962, p. 54.

66. Apud PAUL DE VISSCHER: op. cit., p. 563. 
Sómente podem na Inglaterra, produzir efeitos as convenções internacionais que, para tanto, por fôrça do Parlamento, hajam sido incorporadas ao Direito interno (casos The Parlement Belge, 1880; Walker v. Baird, 1892; Porter. $v$. Freudenberg, 1915). O que os tribunais inglêses aplicam é a norma de direito interno em vigor. Não lhes compete controlar a conformidade ou a contrariedade da legisłação inglêsa com o Direito internacional. É o que se decidiu no caso Mortensen v. Peters: "In this Court we have nothing to do with the question whether the Legislature has or has not done what foreign powers may consider an usurpation in a question with them. Neither are we so, this Court, in its instance juridiction at least, would be bound ultra vires as in contravention of generally acknowledged principles of international law. For us an Act of Parliament duly passed by Lords and Commons and assented to by the King it is supreme, and we are bound to give effect to its terms" 67 .

Jurisprudência similar é a norte-americana, tal como se divisa no aresto proferido, em começo do século passado, na questão Foster and Elam v. Nelson, em que estava em causa a interpretação do Tratado de paz de Ildefonso, de $1 .^{\circ}$ de outubro de 1800: "We think then, however, individual judges might construe the treaty of Ildefonse, it is the province of the Court to conform its decisions to the will of the legislature, if that will has been clearly expressed." Tratados e leis estão colocados, pela Constituição, em pé de igualdade. Leis federais, esclareça-se. Porque a supremacia do tratado é absoluta "em relação ao direito dos Estados que compõem a União" ${ }^{68}$. Sôbre a equiparação do tratado e da lei federal, esclarecia o juiz Taft, em sentença de 1888 sôbre a questão Whitney $v$. Robertson: "By the Constitution a treaty is placed on the same footing, and

67. Apud Walz: op. cit., p. 402.

68. ERIC STEIN: Toward Supremacy of Treaty-Constitution by Judicial Fiat in the European Economic Community, in "Rivista di Diritto Internazionale", vol. XLIIII (1965), fasc. 1, p. 43. 
made of like obligation with an Act of legislation... if the two are inconsistent, the one last in date will control the other, provided always the stipulation of the treaty on the subject is self executing. . The duty of the Courts is to construe and to give effect to the latest expression of the sovereign will" 69 . Numerosas decisões jurisprudenciais sustentam essa mesma tese.

A jurisprudência germânica prolonga a tradição weimariana, a do reconhecimento de igualdade hierárquica entre convenção e lei. Tem essa jurisprudência apoio no artigo 59 da Lei Fundamental de Bonn que, ao prever a aprovação dos tratados na forma do processo legislativo comum, acaba lhes conferindo fôrça de leis federais ${ }^{70}$. Em outros países europeus também persiste a tese da equiparação entre lei e tratado: na Suíça ${ }^{71}$, na Belgica ${ }^{72}$, na Austria ${ }^{73}$.

Cite-se, no continente americano, a jurisprudência argentina. Embora haja entendimento em favor da primazia da convenção internacional sôbre a legislação ordinária ${ }^{74}$, parece predominar a tese contrária, tal como se explicita em decisão da Côrte Suprema, relativa ao caso "Martin y Cia., S. A. c. Nación Argentina" 75.

O reconhecimento da preeminência hierárquica do tratado sôbre a lei tem, em contraposição, o apoio da doutrina monista que parte do pressuposto de que, entre ambas as normas, é possível conflito. Não necessita o tratado

69. Apud PaUl de Visscher: op. cit., p. 563.

70. LARDY: op. eit., pp. 80-81.

71. GugGenheim: Enquête, p. 14 e LaRdy: pp. 242-243.

72. WALZ: pp. 80-82.

73. CоMтE: pp. 124-125.

74. Cf. BIDART Campos, op. cit., p. 130.

75. "Fallos", tomo 257, p. 99, 1963, apud BIDART CAMPos, ibidem, - Pablo A. Ramella: Antecedentes de la República Argentina, relatório apresentado à Mesa Redonda sôbre La Integración de América Latina y la Cuestión Constitucional, Bogotá, 6/8 fevereiro de 1967. 
de transformar-se ao penetrar a esfera estatal. Nela permanece tal qual é. Encontra êsse reconhecimento, outrossim, o arrimo de convenções internacionais: Pacto da sDN e Carta da onu (Preâmbulo); Carta de Bogotá (art. 14); tratados bilaterais como o germano-suíço de arbitragem e conciliação, de 10 de setembro de 1923 ou o acôrdo brasileiro-uruguaio, de 5 de setembro de 1948.

Também no Direito interno subsiste o reconhecimento dessa superioridade hierárquica da convenção internacional.

É o que o demonstra o Direito espanhol, aliás, de longa data. Já o Real Decreto, de 8 de agôsto de 1864, precrevia que "no puede modificarse por la sola voluntad de una parte, y sin la aquiescencia de la otra, lo estipulado en un pacto bilateral". Era o que, outrossim, proclamava a Constituição espanhola de 1931: "Tôdas as convenções internacionais ratificadas pela Espanha e registradas na Sociedade das Nações e que têm o caráter de leis internacionais" — dizia o art. 65,1 . $^{\mathrm{a}}$ alínea- "serão consideradas como partes constitutivas da legislação espanhola, que deverá ser adaptada a suas disposições". Aduzia êsse mesmo artigo (2. ${ }^{\mathrm{a}}$ alínea) que o govêrno não faria lei que contrariasse essas convenções a não ser que houvessem sido prèviamente denunciadas de conformidade com processo nelas estabelecido. A jurisprudência tem perfilhado a mesma tese, não obstante revogação dessa Constituição. Depois de estudar a eficácia dos tratados internacionais contemporâneos na ordem jurídica de seu país, observa Pastor RIDRUEJO 76: "Los órganos estatales aplican continuamente tratados, observándose perfectamente dicha aplicación en la actuación de los tribunales, que no sólo los hacen prevalecer sobre las leyes, sino que los toman en cuenta aun no siendo aplicables al caso de autos e, incluso, en una ocasión, tratándose de un acuerdo que no obligaba a España."

76. Op. cit., pp. 50-59. 
Também antigo é o reconhecimento, pela jurisprudência de Luxemburgo, da primazia dos pactos internacionais sôbre qualquer fonte normativa de Direito interno. Assinala-o Nicola Catalano ${ }^{77}$.

A Constituição francesa de 1946 teve o mérito de ressaltar, em duas disposições, a superioridade dos acôrdos internacionais em relação às leis internas. "Les traités diplomatiques régulièrement ratifiés et publiés" - dispõe o art. 26- "ont force de loi dans le cas même où ils seraient contraires à des lois internes françaises, sans qu'il soit besoin pour en assurer l'application d'autres dispositions legislatives que celles qui auraient été nécessaires pour assurer leur ratification". Aduz o art. 28 da mesma Constituição: "Les traités diplomatiques régulièrement ratifiés et publiés, ayant une autorité supérieure à celle des lois internes, leurs dispositions ne peuvent être abrogées, modifiées ou suspendues qu'à la suite d'une dénonciation régulière, notifiée par voie diplomatique. Lorsqu'il s'agit d'un des traités visés à l'art. 27, la denonciation doit être autorisée par l'Assemblée nationale, exception faite pour les traités de commerce." Mantém a Constituição vigente (de 1958) as mesmas diretrizes, mas de certa forma restringindo-as porque passou a condicionar expressamente o princípio da superioridade da norma convencional a uma reciprocidade de fato. Não obstante serem os termos dêsses dois diplomas franceses mais incisivos e menos programáticos que a Constituição espanhola de 1931, a jurisprudência francesa não tem mostrado a mesma firmeza que a espanhola no proclamar a regra da preeminência dos tratados internacionais. Mostra-se aquela hesitante e recorre com frequência a interpretação governamental que,

77. La Posición del Derecho Comunitario dentro del Derecho de los Estados Miembros, in "Relaciones entre el Derecho Comunitario y el Derecho Nacional", Instituto Interamericano de Estudios Internacionales, 1967, p. 196. 
via de regra, tende a manifestar-se em favor da aplicação da lei interna ${ }^{78}$.

Sem estar limitada por condição de reciprocidade, e incluindo em seu âmbito os tratados solenes e os acôrdos de forma simplificada, a Constituição holandesa, mercê das revisões de 1953 e de 1956, é a que de modo mais enfático ressalta a superioridade dos tratados internacionais. "As prescrições legislativas em vigor no Reino" - declara o art. 66 da Carta Magna neerlandesa- "não são aplicáveis se colidirem com disposições de tratado que imponha obrigações aos particulares, e concluido anterior ou posteriormente à entrada em vigor dessas disposições."

Têm sido omissas a respeito as constituições brasileiras. Mas lei recente, n. 5.172, de 25 de outubro de 1966, preceitua: "Os tratados e as convenções internacionais revogam ou modificam a legislação tributária interna, e serão observados pela que lhes sobrevenha." Explicita essa norma o que, nos setores mais amplos e não adstritos à matéria tributária, vem decidindo a jurisprudência brasileira. É o que ressaltou Philadelpho Azevedo em estudo publicado em 194579 . É o que também põe em relêvo Haroldo ValLADÃo, após ter examinado a jurisprudência inclusive posterior à data da publicação daquele ensáio ${ }^{80}$.

Conclusão similar é a que, em relação ao Direito de seu país, formula CÉSAr SePúlveda, ao examinar a jurisprudência mexicana ${ }^{81}$.

78. Cf. LARDY: pp. 160-161.

79. Os Tratados e os Interêsses Privados em face do Direito Brasileiro, "Boletim da Sociedade Brasileira de Direito Internacional", n. 1, pp. 12-29.

80. Cf. Fontes do Direito Internacional Privado e Conflitos entre as Internacionais $e$ as Internas, in "Revista da Faculdade de Direito de Pelotas", 1962, pp. 46-47. Sôbre diretriz da doutrina, cf. nosso La Procédure de Conclusion des Accords Internationaux au Brésil, in "Revista da Faculdade de Direito", Universidade de São Paulo, 1960, pp. 264-265.

81. Op. cit., pp. 67-70. 
Em relação ao Direito venezuelano, tem especial importância o que dispõe o Código de Procedimiento Civil, cujo artigo $8 .^{\circ}$ declara: "Én los casos de aplicación del Derecho Internacional Privado los jueces atenderán primero a los tratados públicos de Venezuela con la nación respectiva, en cuanto al punto en cuestión; en defecto de tales tratados, aplicarán lo que sobre la materia dispongan las leyes de la República o lo que se desprenda de la mente de la legislación patria; y en último lugar, se regirán por los principios de dicho Derecho aceptados generalmente." Esse artigo - como explica Febres Pobeda ${ }^{82}$ - "que data hace bastante años", reflete "el espíritu cosmopolita" que tem sempre animado a legislação venezuelana.

Quanto aos efeitos do Direito interno sôbre os órgãos internacionais, comecemos por observar que não costumam èsses órgãos distinguir entre a atividade legislativa e as demais que o Estado exerça. Nenhuma diferença acolhem entre as normas internas, nenhuma eventual hierarquia que as estratifique ou escalone. Ilustrativa, a propósito, a sentença da CPJI, de 25 de março de 1926: "do ponto de vista do Direito Internacional e do Tribunal que é o seu órgão, as leis internas são simples fatos, manifestação da vontade e da atividade do Estado, da mesma maneira que suas resoluções judiciais ou suas medidas administrativas" 83 . Como fato a ser examinado em processo internacional, deve a lei não apenas ser alegada senão também provada.

Ao tomar a lei interna como simples fato, não deixarão as instâncias internacionais, contudo, de tomá-la em consideração sobretudo para avaliar de sua conformidade com as normas do Direito das gentes. Esclareceu a CPJI, a propósito de conflito de interêsses germano-poloneses, que, embora não lhe coubesse interpretar lei interna, nada a impedia de julgar se, ao cuidar de aplicá-la, estaria ou

82. Apuntes de Derecho Internacional Privado, $2 .^{\mathrm{a}}$ ed., Mérida, 1962 , p. 234.

83. CPJI, série A, n. 7, pp. 19 e 81. No mesmo setido: CIJ, Recueil 1955, pp. 35, 36 e 51 . 
não a Polônia agindo de conformidade "com suas obrigações internacionais em relação à Alemanha" ${ }^{84}$. Também a Côrte Permanente de Arbitragem entendera conhecer da conformidade das leis norte-americanas com o Direito internacional, ao apreciar a licitude da requisição de naves norueguesas pelos Estados Unidos.

A superioridade do tratado em relação às normas de Direito interno é consagrada pela jurisprudência internacional.

Da Côrte Permanente de Justiça Internacional citam-se as seguintes sentenças: $a$ ) de 17 de agôsto de 1923, na questão Wimbledon: "une ordonnance de neutralité, acte unilateral d'un Etat, ne saurait prévaloir sur les dispositions du traité de paix" ${ }^{85} ; b$ ) e de 7 de junho de 1932 , no caso das zonas francas entre a França e a Suíça: "un Etat ne saurait se prévaloir de sa législation pour restreindre la portée de ses obligations internationales" ${ }^{86}$. Do mesmo tribunal, mencionam-se os seguintes pareceres consultivos: a) de 10 de setembro de 1923, na questão dos interêsses alemães na Polônia ${ }^{87} ; b$ ) de 21 de fevereiro de 1925 , na questão da permuta das populações gregas e turcas ${ }^{88} ; c$ ) de 31 de juIho de 1930 , no caso das comunidades greco-bulgaras ${ }^{89}$. Foi bem explícita neste último caso a Côrte: "C'est un príncipe généralement reconnu du Droit des gens que, dans les rapports entre Puissances contractantes d'un traité, les dispositions d'une loi interne ne sauraient prévaloir sur celles du traité."

Essa mesma diretriz é perfilhada pela Côrte Internacional de Justiça; a) a sentença de 27 de agôsto de 1952 entendeu que decreto do Presidente Geral da República francesa atentava contra os direitos dos Estados Unidos defi-

84. CPJI, série A, n. 7, pp. 19 e 81.

85. Publications de la Cour, série AB, n. 5, p. 29.

86. Ibidem, série $\mathrm{AB}, \mathrm{n} .46$, p. 167.

87 Ibidem, série $\mathrm{AB}, \mathrm{n} .6$, pp. 23 e segs.

88. Ibidem, série $\mathrm{AB}$, n. 12, p. 20.

89. Ibidem, série $\mathrm{AB}$, n. 37, p. 32 . 
nidos pelo Ato de Algesiras (caso dos direitos dos cidadãos norte-americanos no Marrocos) ${ }^{90}$; $b$ ) na questão do ouro monetário apreendido em Roma, em 1943, a sentença de 15 de junho de 1954 explicou que a decisão de mérito dependia da questão de saber se uma lei albanesa era conforme com o Direito internacional ${ }^{91}$.

Entre as sentenças arbitrais, que perfilham a mesma tese, citemos como paradigma a de 21 de outubro de 1861, proferida pelo Senado de Hamburgo, a propósito do litígio entre a Grã-Bretanha e Portugal na questão Yuille-Shortdridge: reconhecimento da prevalência do tratado angloportuguês de 10 de julho de 1654 sôbre leis portuguêsas ${ }^{92}$. Outras sentenças arbitrais se podem acrescentar, outrossim, embora ferindo mais o problema da responsabilidade internacional: a) de 23 de julho de 1875, entre os Estados Unidos e a Colombia, caso do navio Montijo ${ }^{93}$; $b$ ) de 4 de dezembro de 1888 entre os Estados Unidos e Haiti, na questão Van Pokkelen ${ }^{94} ; c$ ) de 30 de dezembro de 1896 , entre a França e a Venezuela, no caso Fabiani ${ }^{95} ; d$ ) de 18 de outubro de 1923, entre a Grã-Bretanha e Costa Rica, na questão Tinoco ${ }^{96}$.

Impõe-se, a nosso ver, de forma irrecusável, o reconhecimento da primazia da norma internacional. É o que a razão humana compreende, o que recomenda a noção de unidade e solidariedade do gênero humano, essa consciência do respeito à "família de nações", que estava tão ardente nos ensinamentos de Vitória e dos clássicos do século XVI. Esse reconhecimento deflui normalmente de princípios jurídicos fundamentais, tal o pacta sunt servanda

90. C.I.J., Recueil 1952, p. 185.

91. Question préliminaire, C.I.J., Recueil 1954, p. 32.

92. La Pradelle e Politis, tomo II, p. 106.

93. LAFOntaine: op. cit, p. 210 ; MoORE: Digest of International Arbitration, p. 1440.

94. La Fontaine: op. cit., pp. 309 e segs.

95. Ibidem, pp. 344-369.

96. "AJIL", 1924, pp. 159-160. 
e o voluntas civitatis maximae est servanda. A única exceção à prevalência do tratado internacional a admitir-se é aquela em que, como vimos no capítulo IV, tenha sido êle concluido com transgressão manifesta de norma interna anterior concernente à competência para concluir normas convencionais (e desde que a parte reclamante não haja anteriormente reconhecido a validade do tratado cuja nulidade pleiteia). Nessa hipótese excepcional, nem há de se falar, aliás, em prevalência de norma interna, mas a rigor, de nulidade do tratado posterior por infringência de requisito essencial.

O prestígio indiscriminado das normas internas, ou a equiparação delas com os tratados internacionais, acabam concorrendo, não há de negar, para o enfraquecimento do Direito das gentes.

A solução ao problema da incompatibilidade entre pactos internacionais e Constituições estatais parece oferecer, contudo, aspectos diferentes que devem ser tidos na devida conta. Essas constituições ordenam o Estado cuja autonomia cumpre ser salvaguardada, como condição da própria ordem e progresso da comunidade internacional. Examinemos a seguir os aspectos particulares que podem envolver esta modalidade de conflito.

\section{VIII.}

\section{Conflito entre Tratados e Leis Constitucionais.}

A predominância dos tratados internacionais sôbre as leis internas tem, como se verifica, completo arrimo na jurisprudência internacional. Encontra apoio também nas demais fontes do Direito das gentes; nas convenções, nos costumes internacionais, nos princípios gerais de Direito, na doutrina. Dizemos na doutrina, porque os próprios dualistas, embora afirmem a validade na ordem interna das leis conflitantes com tratados internacionais, negam essa 
validade em relação à ordem inter-estatal, reconhecendo, em conseqüência, a responsabilidade internacional do Estado no qual aquelas leis tiverem curso. Responsabilidade oriunda de ato ilícito, por certo, ou seja, de descumpri-. mento de compromissos contraídos, de transgressão da palavra empenhada. Não há negar que a tese dualista não satisfaz plenamente às exigências básicas da convivência social, na qual o Direito positivo se fundamenta. $\mathrm{E}$ não condiz também com a unidade do próprio Direito cujas diretrizes devem convir, simultâneamente, para os diferentes sistemas jurídicos, que todos pertencem a mesma ordem jurídica geral.

$O$ acolhimento da tese da primazia dos tratados internacionais conduz, sob prisma estritamente lógico, à proclamação dessa superioridade em relação às leis internas, quaisquer que sejam as modalidades a que pertençam. Superioridade inclusive em relação às Constituições nacionais. É a conclusão que, por estrita coerência doutrinária, acolhem numerosos juristas, entre os quais os mais conhecidos talvez sejam Kelsen e Scelle.

Predominância do tratado em relação às leis ordinárias posteriores? Sim, como verificámos no capítulo anterior. Prevalência em relação também às leis constitucionais posteriores? Sim, por fôrça do princípio da superioridade hierárquica da norma convencional. Foi o que asseverou a Côrte Permanente de Justiça, no parecer consultivo (n. 23), de 4 de fevereiro de 1932: "um Estado não pode invocar a sua própria Constituição para subtrair-se às obrigações do Direito internacional e dos tratados" 97. Interpretara a Côrte o artigo 104, alínea 5. ${ }^{\mathrm{a}}$, do Tratado de Versalhes e o artigo 33, alínea $1 .^{\mathrm{a}}$, da Convenção de Paris de 9 de novembro de 1920 , em relação à situação dos cidadãos poloneses e demais pessoas de origem ou de idioma poloneses, no território de Dantzig. A sentença arbitral, de

97. Publications de la Cour Permanente de Justice Internationale, série A/B, n. 44, p. 24. 
19 de outubro de 1928, referente ao litígio franco-americano na questão George PINson, declarou, da mesma forma: na hipótese da preexistência de tratados, "esta mesma circunstância impedirá de modo absoluto ao Estado, promulgar validamente disposições constitucionais contrárias a tais tratados". .

Superioridade do tratado, outrossim, em relação às leis ordinárias anteriores? Sim, como verificámos no capítulo anterior. Superioridade em relação também às leis constitucionais anteriores? Sim, tanto por fôrça do princípio da preeminência hierárquica da norma internacional como em atenção ao aforismo "Lex posterior.. ", mas com uma exceção básica, a que fizemos menção no capítulo IV, a saber: Se o tratado houver sido concluído com violação manifesta da norma interna concernente à competência para concluir normas convencionais (e desde que a parte reclamante não haja anteriormente reconhecido a validade do tratado cuja nulidade pleiteia), então, nesse caso, não prevalece êsse tratado. E por que não prevalece? Porque o tratado não chegou a ser regularmente concluído. Não há, com essa solução, a rigor, primazia da norma interna sôbre o tratado internacional posterior. O que ocorre é nulidade dêsse mesmo tratado por não haver atendido aos pressupostos constitucionais necessários para a sua conclusão.

Como expõe Mervyn Jones, pode o Estado organizar, como deseja, seu sistema de competências. Ele indica as: autoridades capazes e o processo adequado para concluir tratados. São restrições constitucionais concernentes à vaIidade formal do tratado e devem ser cumpridas. Existem, outrossim, restrições constitucionais que proibem tratados de determinada espécie, e são internacionalmente ineficazes. A validade formal das convenções é determinada pelo Direito interno, enquanto a validade material delas, é questão substancial, e não pode ser por êsse Direito regulamentada, "But a treaty perfect in point of form cannot be declared null or be affected by reason of a conflict between 
its provisions and the law of the parties". A razão é clara: "a State cannot by its unilateral act prescribe the subjects. on which international law, through treaties, can be made" 98 .

Essas disposições constitucionais concernentes à validade formal, cuja transgressão acarreta a nulidade do tratado, dizem respeito à elaboração dêsse tratado. Não há confundi-las com disposições constitucionais concernentes à execução do tratado. A infringência destas últimas não determina essa nulidade. O descumprimento da convenção - como lembra ARÉCHAGA ${ }^{99}$, tendo por base o caso Missouri v. Holland- "no afecta la fuerza obligatoria del tratado".

Importa considerar, porém, que o reconhecimento do primado completo dos acordos internacionais sôbre as Constituições dos Estados contratantes, oferece na prática dificuldades, inclusive porque a tramitação dêsses acôrdos não costuma seguir as formalidades rigorosas que a elaboração das leis constitucionais reclama. Cumpre ademais ponderar que a afirmação dêsse primado pode conduzir ao desconhecimento da realidade social, política e humana que cada Estado encarna, realidade essa que as leis conslitucionais refletem e consolidam. A existência do Estado precede, aliás, no tempo à da própria ordem internacional e continua a afirmar-se concretamente, embora com cerceamentos, no estágio atual de evolução do Direito e da sociedade.

Entre os poderes que o Estado usufrui está o de organizar-se a si próprio e o de estabelecer ou interromper a comunicação entre a ordem interna e a ordem internacional. "Mesmo se um Estado acolhe ao máximo as normas internacionais em seu Direito interno" - adverte MosLer ${ }^{100}$ - "mesmo se êle dispõe sôbre a superioridade das normas

98. Full Powers and Ratification, Cambridge University Press, 1949, pp. 151-152.

99. I, p. 241.

100. Op. cit., p. 640. 
jnternacionais sôbre as da sua própria Constituição, é preciso não esquecer que se trata de concessões que assumem a forma constitucional". Difícilmente haverá de o Estado pura e simplesmente negar a sua própria autonomia e mesmo não convém que o faça, já que os interêsses seus podem e devem se harmonizar com os interêsses da sociedade internacional. É numa perspectiva de cooperação e de federalismo que se deve entrever as relações entre a ordem interna e a internacional. Errônea é a tese que tenda a exaltar uma ao prêço da destuição da outra.

É de certo modo compreensível conste de constituições a regra de que sôbre elas não prevaleçam os tratados; ou então, que no silêncio delas, dêsse mesmo entendimento prevaleçam a jurisprudência e a prática nacionais. Desta última hipótese, são exemplos os Estados Unidos ${ }^{101}$ e os Estados centro-americanos ${ }^{102}$. Norma expressa integra a Constituição argentina; segundo o artigo 27, a obrigação do Govêrno Federal em "afianzar sus relaciones de paz y comercio con las potencias extranjeras" sòmente subsiste "por medio de tratados que estén en conformidad con los principios de derecho público establecidos en esta ConstiIución". Estudo de Isidoro Ruiz Moreno, publicado na Revista Argentina de Derecho Internacional, de 1940, transcreve disposições constitucionais com propósito similar: a do Equador (art. 161) e do Haiti (art. 127), entre outras. Podemos fazer ainda menção de disposições das seguintes constituições posteriores à publicação dêsse estudo: art. 47, n. 2, de El Salvador (de 1962); artigo 189, de Equador (aprovada em 1946, modificada em 1948 e 1960); art. 246, da Guatemala (1965) ; artigo 133, do México (aprovada em 1917, com modificações posteriores); art. 324, da Nicaragua (aprovada em 1962, com modificações posterio-

101. Cf. Cowles: Treaties and Constitutional Law, 1942, pp. 301302.

102. Cf. Problemática Jurídica e Institucional de la Integración de América Latina, Wáshington, 1967, pp. 714-717. 
res). Tem sido assinalado que essas disposições - em favor da superioridade constitucional - não possuem caráter tão absoluto quanto parecem ostentar ${ }^{103}$.

Ao referir-se à Constituição argentina, escreve BIDART Campos: "Aunque no está dicho expressamente, es evidente que siendo la Constitución rigida, y exigiendo por ello un mecanismo específico de reforma, el tratado a través del cual el Estado se obliga por voluntad de los órganos de su poder constituido, no puede alterar la Consfitución, porque si así fuera se admitiria una reforma de la misma Constitución por vías extrañas a las que ella ha ordenado para el poder constituyente derivado" 104 .

Estas palavras nos encaminham para a solução que a nosso ver deve ser dada ao problema do conflito entre Constituição e tratado internacional. Não o reconhecimento do primado absoluto da Constituição sôbre o tratado internacional, porque seria ignorar as razões em favor da preeminência das normas internacionais sôbre as internas; e nem, por outro lado, o reconhecimento do primado absoluto do tratado sôbre as leis constitucionais porque seria desconhecer a importância delas na ordem jurídica bem como seria atentar contra a autonomia e a realidade social e política de cada Estado. A solução reside em compreender que a afirmação da predominância dos tratados sôbre as leis constitucionais (que é a regra de princípio a ser acolhida) envolve um problema técnico de emenda constitucional, que deve ser especialmente previsto e regulamentado em cada Estado. Admitir a predominância dos tratados internacionais é admitir, de certo modo, a modificação da própria Constituição. A conclusão dos tratados que tem êsse alcance há de obedecer aos requisitos da

103. Cf. Problemática, op. cit., pp. 779-787.

104. Op. cit., p. 125. 
tramitação não de lei ordinária mas dos de tramitação especial, como os necessários para emenda da própria Constituição.

É o entendimento que tem prevalecido em face do Estatuto fundamental (Grundgesetz) da Alemanha Ocidental (de 23 de maio de 1949). Pelo fato de possuirem a mesma fôrça interna que as leis federais, estão os acôrdos, tanto quanto estas leis, subordinados à autoridade da Constituição. A conclusão de tratado que conflite com o Estatuto Fundamental importa em revisão constitucional, o que demanda apresentação de lei especial cuja aprovação depende do voto favorável de dois terços dos membros da Dieta federal e de dois terços dos votos de Conselho Federal. Não pode o Congresso aprovar, pois, êsse tratado com a observância do processo de tramitação das leis ordinárias.

Solução similar acolhe a Constituição francesa de 1958, cujo artigo 54 dispõe: "si le Conseil constitutionnel, saisi par le Président de la République, par le Premier Ministre ou par le Président de l'une ou l'autre assemblée, a déclaré qu'un engagement international comporte une clause contraire à la Constitution, l'autorisation de le ratifier ou de l'approuver ne peut intervenir qu'après la révision de la Constitution". Essa revisão exige processo de tramitação rigoroso. Deve o respectivo projeto ser, inicialmente, votado pelas duas Casas do Congresso. É, a seguir, submetido ao referendum popular, a não ser que o Presidente da República prefira submeter o mesmo projeto às Casas parlamentares que se reunirão em sessão conjunta e que deverão aprová-lo por maioria qualificada (de três quintos).

É dentro da mesma perspectiva que se insere a solução do Direito holandês, mercê das revisões constitucionais de 1953 e 1956. Diferença se estabelece, porém, em relação. aos sistemas germânico e francês. Dispõe o artigo 63 da Constituição holandesa: "Se a evolução da ordem jurídica 
o exigir, tratados que derroguem a Constituição poderão ser concluidos. Nesse caso, a aprovação deve ser concedida expressamente; as Câmaras dos Estados gerais não poderão adotar o projeto de lei apresentado a êsse fim senão mediante maioria de dois terços dos votos colhidos". Este processo de tramitação é menos rigoroso do que o da revisão constitucional pròpriamente dita e mais rigoroso, por outro lado, do que o processo de aprovação das leis ordinárias. Obedece por inteiro, como se sabe, aos propósitos superiores de solução ao problema do conflito entre tratados e Constituições, o de conciliar as exigências politicas da soberania nacional com os princípios da primazia dos tratados sôbre o Direito interno.

Mencione-se ainda solução da Constituição austríaca, tal qual foi revista a 4 de março de 1964. Os tratados que com ela conflitarem sòmente serão concluidos nas condições exigidas para a revisão constitucional, a saber, pela Câmara dos Deputados (Nationalrat), por maioria de dois terços dos votos. Ademais, deve a lei de aprovação conter disposição em que se confirme expressamente que o tratado derrogou a Constituição. Se o tratado não atender a êsses requisitos, a Côrte constitucional o declarará inconstitucional e recusará reconhecer-lhe a validade 105 .

Seriam modificáveis, por via de tratados internacionais, mesmo observados os requisitos da revisão constitucional, tôdas as normas da Magna Carta? Parece que, nessa matéria, se há de atender ao chamado "conteúdo irredutível" da Constituição. Não se modificará o que a própria Constituição proiba seja susceptível de modificação (verbi gratia: art. 139 da Const. italiana e art. 50, $\S 1^{\circ}$, da Const. brasileira). Afirmar a impossibilidade de reformar a Constituição, por meio de convenções internacionais, naquilo que ela própria proibe, se justifica pelo princípio

105. LARDY: op. cit., p. 175 , nota n. 32 , in fine. 
da incompetência formal dos órgãos governamentais em concluir tratados internacionais.

O florescimento das instituições internacionais, mormente as de caráter comunitário, tem estimulado o exame da compatibilidade entre o tratado básico dessas instituições e a constituição dos Estados membros. A experiência tem demonstrado que, via de regra, essa compatibilidade é admitida. O que ocorreu com os tratados de integração européia parece expressivo, uma vez que foram aprovados de acôrdo com processos parlamentares normais (excepcionalmente recorreu-se, no Luxemburgo, a tramitação especial), com apoio da jurisprudência, embora por vêzes com restrição da doutrina (caso de Vedovato, por ex., na Italia). A mesma compatibilidade tem sido reconhecida nas questões suscitadas em tôrno dos tratados da Comunidade centro-americana e da Associação latino-americana de Livre Comércio, assim como do eventual Tratado de integração latino-americano que está sendo objeto de debate e projetos ${ }^{106}$.

IX.

As Sanções.

O acolhimento da tese monista - a da prevalência da norma internacional inclusive no Direito interno possui o mérito de eliminar antinomia com que o Estado concorre para transgredir aquela norma. Evita-se, desse modo, êsse pecado mortal contra a ciência, a que faz menção Kunz, e consistente em "voiler par des artifices quasijuridiques la violation du droit des gens" 107 .

106. Cf. Problemática, pp. 717 e segs.

107. Cf. La Primauté du Droit des Gens, in "Revue de Droit International et de Législation Comparée", 1925, pp. 556 e segs. 
Todavia, subsiste o Direito internacional, em grande parte, como um sistema de coordenação entre Estados, deixando-lhes intacta a organização interior. Não dispõe ainda a ordem jurídica internacional do poder de dar cumprimento aos tratados mesmo na hipótese em que o Estado os desconheça ou transgrida. Privada de órgãos centralizados e dos meios para impor diretamente suas determinações, recorre ela à colaboração estatal.

Não tem, em conseqüência, apoio na realidade afirmação de monistas, como a de Georges Scelle, de que o Direito internacional "abroga automàticamente" o Direito interno "desde que com êle seja incompativel" ${ }^{108}$. Esta modalidade de sanção não se compadece com a estrutura da sociedade internacional na qual os Estados permanecem, como se disse, como titulares de competência própria. 'Tendo em conta os dados da realidade, compreende-se haja Kelsen se afastado de posição ortodoxa inicial, em que sustentava ser nula $a b$ initio norma interna conflitante com internacional; e passasse a admitir tanto a hipótese de anulação da norma hieràrquicamente inferior como também a de sanção contra o órgão responsável pelo ato ilícito. Poder-se-á, pois, admitir - escrever Kelsen - a validade da norma interna até o momento de sua anulação ou mesmo a sua validade indefinida se essa anulação não fôr alcançada pela ordem internacional ${ }^{109}$. E o fato de permanecer válida a norma hieràrquicamente inferior, até a sua devida anulação, nada tem de excepcional, pois o mesmo ocorre na ordem interna: o regulamento em face da lei; e a lei ordinária em face da constituição ${ }^{110}$.

108. De la prétendue inconstitutionalité interne des traités, in "Revue de Droit Public et de Sciences Politiques", 1952, p. 1016.

109. Théorie du Droit International Public, op. cit., p. 194.

110. Cf. VAlladão: Eranion in honorem Marikadis, vol. III, Atenas, 1964, pp. 534-541; AREchaGA: Curso, I, pp. 220-221; TRUYol: Noções Fundamentais, p. 111. 
Ora, se se tem por assentado que o contencioso internacional é eminentemente de reparação e que o Estado cuja norma interna contrariar a internacional pode ser compelido a pagar indenização ou compensar a parte prejudicada "satisfactoria y equitativamente en otra forma", sem prejuízo da validade interna dessa norma, pode-se e deve-se caminhar para sistema de sanção mais aperfeicoado que traduza índice de cooperação maior entre os Estados. Precedentes fecundos se encontram no sistema de agências especializadas das Nações Unidas e no Direito comunitário.

A institucionalização do contencioso de anulação de leis dos Estados da Comunidade hispano-luso-americana, conflitantes com tratados de que êsses Estados sejam partes, é solução que se of erece para o fortalecimento dos vínculos de mútua solidariedade.

E solução, porém, que não elimina outra que se afigura superior: a de que os próprios Estados evitem, na área de competência que lhes é própria, a colisão de suas normas internas com os compromissos assumidos na ordem internacional.

\section{$\mathrm{X}$.}

\section{Conclusões.}

Como corolário do que acima se expôs, inferimos as seguintes conclusões:

$10^{\circ}$ O conflito dos tratados internacionais com a ordem estatal não é senão aspecto particular, mas essencial, de problema de maior âmbito, o das relações entre Direito interno e Direito das gentes. Esse conflito sublinha a necessidade de transcender o debate polêmico das escolas doutrinárias e de levar em conta a realidade do Direito tal como é elaborado e pôsto em execução. 
2. As soluções propostas pela doutrina valem na medida em que tenham inserção na realidade política e social dentro da qual o problema do conflito entre norma estatal e tratado está equacionado. Importa rejeitar as soluções que se reduzem a méro verbalismo, ao desconhecimento dos diversos graus de convivência humana e à negação do próprio Direito internacional.

$3 .^{\circ}$ O problema das relações do tratado internacional com a ordem jurídica estatal deve ser considerado através de dupla perspectiva: a emanada do Direito das gentes e a emanada do Direito interno. São vias que conduzem a resultados fecundos e permitem comprovar que as ordens jurídicas não são radicalmente separadas mas se condicionam e se influenciam mutuamente e constituem esferas da mesma ordem jurídica geral.

4..$^{\circ}$ Mesmo na fase atual de evolução da sociedade internacional, o Estado continua a ser o instrumento indispensável de formação e de execução das normas convencionais. Cabe-lhe dispor sôbre a maneira pela qual elabora os tratados, decidir se os considera parte integrante do ordenamento interno e determinar soluções para o conflito dêles com a ordem jurídica nacional.

5. ${ }^{\circ}$ Assumem importância capital as leis de cada Estado, mormente as constitucionais, e que se relacionem com a conclusão e os efeitos das convenções internacionais. Cumpre a essas leis concorrer para o apressamento da tramitação dos tratados e determinar com rigor os casos em que êles demandem ou não a aprovação prévia de órgãos governamentais competentes.

6. ${ }^{\circ}$ Devem as normas jurídicas estatais dispor não apenas sôbre as condições de validade dos tratados senão também sôbre as garantias técnicas e processuais que lhes assegure a eficácia na ordem interna. A clareza e a pre- 
cisão dessas normas concorrerão tanto para o aprimoramento da ordem internacional como para o resguardo dos interêsses legítimos de cada Estado.

7. 0 conflito entre tratado internacional e norma interna pressupõe estarem ambos devidamente concluídos. Concorrem para restringir a freqüência dêsse conflito a regra de interpretação legi speciali per generalem non derogatur; a presunção de compatibilidade entre normas internas e internacionais; a noção de pacto non self executing; e eventual relação hierárquica entre acôrdos internacionais.

8. ${ }^{\circ}$ A solução ideal e desejada é a da harmonização das ordens juridicas de cada Estado com a ordem jurídica internacional. A tendência de várias Constituições contemporâneas é a de concorrer para essa harmonização. Fortalece essa tendência admitir que os tratados, tão logo sejam regularmente concluídos e produzam efeitos na

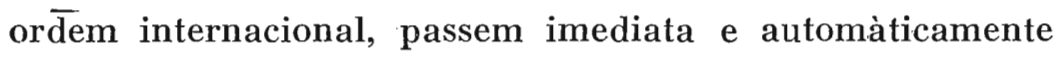
a produzi-los na ordem interna dos Estados contratantes.

9. ${ }^{\circ}$ Também concorre para fortalecer essa harmonização, o reconhecimento, pela jurisprudência de cada Estado, da superioridade hierárquica de tratado sôbre o Direito interno, de conformidade com o que vêm decidindo reiteradamente os tribunais internacionais.

$10 .^{\circ}$ Em favor da preeminência hierárquica de tratado sôbre as normas internas, se manifestam convenções e a jurisprudência internacional; parte relevante da doutrina; e, outrossim, leis e jurisprudência de vários Estados. É entendimento que prestigia o respeito aos compromissos assumidos, a unidade das relações entre ordens jurídicas e o bem comum internacional. 
11." A prevalência dos tratados sôbre norma interna (constitucional ou não) do Estado contratante pressupõe que êste lhes tenha dado consentimento. É irregular a conclusão de tratados que transgridam manifestamente norma interna anterior, de Estado contratante, concernente à competência para concluí-los. Não é lícito, porém, ao Estado contratante eximir-se do cumprimento dêsses tratados se lhes houver anteriormente reconhecido a validade, implícita ou explícitamente.

12. ${ }^{\circ}$ Cabendo a cada Estado preservar a sua autonomia e respeitar, ao mesmo tempo, a ordem internacional, deve êle organizar-se de tal maneira que êsses dois objetivos sejam igualmente atingidos. A solução reside em compreender que a predominância dos tratados sôbre as leis constitucionais (que é a regra de princípio a ser acolhida) envolve um problema técnico de emenda constitucional, que deve ser especialmente previsto e regulamentado em cada Estado. Admitir a predominância dos tratados internacionais é admitir, de certo modo, a modificação da própria Constituição. A conclusão dos tratados que têm êsse alcance há de obedecer aos requisitos de tramitação não de lei ordinária mas dos de tramitação especial, como os necessários para emenda da própria Constituição.

13. Não são, porém, válidos os tratados que conflitarem com disposições de Constituição anterior que não sejam susceptíveis de emenda.

$14 .^{\circ}$ Desprovida de meios para impor diretamente sua vontade dentro de cada ordem interna, a ordem jurídica internacional recorre à colaboração estatal. Não são nulas automàticamente as normas internas conflitantes com tratados internacionais, se bem que elas possam suscitar a responsabilidade do Estado a cujo ordenamento pertençam. A solução adequada é que o contencioso de anulação acom- 
panhe e substitua, gradualmente, o contencioso de indenização. É solução, contudo, que não elimina outra que se afigura superior: a de que os próprios Estados evitem que suas normas conflitem com as convenções que celebrarem. Entre as formas de evitar êsse conflito, está a de disciplinar com precisão nas leis básicas da organização estatal, a formação, os efeitos e a execução dos tratados internacionais. 